\title{
Recent Advances in Stem Cell Therapy for Limbal Stem Cell Deficiency: A Narrative Review
}

\author{
Ali E. Ghareeb · Majlinda Lako · Francisco C. Figueiredo (D)
}

Received: August 18, 2020 / Accepted: September 15, 2020 / Published online: September 24, 2020

(C) The Author(s) 2020

\begin{abstract}
Destruction of the limbus and depletion of limbal stem cells (LSCs), the adult progenitors of the corneal epithelium, leads to limbal stem cell deficiency (LSCD). LSCD is a rare, progressive ocular surface disorder which results in conjunctivalisation and neovascularisation of the corneal surface. Many strategies have been used in the treatment of LSCD, the common goal of which is to regenerate a self-renewing, transparent, and uniform epithelium on the corneal surface. The development of these techniques has frequently resulted from collaboration between stem cell translational scientists and ophthalmologists. Direct transplantation of autologous or allogeneic limbal tissue from a healthy donor eye is regarded by many as the technique of choice. Expansion of harvested LSCs in vitro allows
\end{abstract}

Digital Features To view enhanced digital features for this article go to https://doi.org/10.6084/m9.figshare. 12957644.

A. E. Ghareeb · M. Lako · F. C. Figueiredo $(\bowtie)$

Biosciences Institute, Newcastle University,

Newcastle-upon-Tyne, UK

e-mail: francisco.figueiredo@newcastle.ac.uk

A. E. Ghareeb - F. C. Figueiredo

Department of Ophthalmology, Royal Victoria

Infirmary, Newcastle Hospitals NHS Foundation

Trust, Newcastle-upon-Tyne, UK smaller biopsies to be taken from the donor eye and is considered safer and more acceptable to patients. This technique may be utilised in unilateral cases (autologous) or bilateral cases (living related donor). Recently developed, simple limbal epithelial transplant (SLET) can be performed with equally small biopsies but does not require in vitro cell culture facilities. In the case of bilateral LSCD, where autologous limbal tissue is not available, autologous oral mucosa epithelium can be expanded in vitro and transplanted to the diseased eye. Data on long-term outcomes (over 5 years of follow-up) for many of these procedures is needed, and it remains unclear how they produce a self-renewing epithelium without recreating the vital stem cell niche. Bioengineering techniques offer the ability to re-create the physical characteristics of the stem cell niche, while induced pluripotent stem cells offer an unlimited supply of autologous LSCs. In vivo confocal microscopy and anterior segment OCT will complement impression cytology in the diagnosis, staging, and follow-up of LSCD. In this review we analyse recent advances in the pathology, diagnosis, and treatment of LSCD.

Keywords: Cornea; Corneal limbus; Corneal transplantation; In vivo confocal microscopy; Limbal niche; Limbal stem cells; Mesenchymal stem cell transplantation; Oral mucosa stem cell 
transplantation; Stem cell transplantation; Tissue engineering

\section{Key Summary Points}

Limbal stem cell deficiency (LSCD) is a rare, blinding corneal disease that results from damage or destruction of limbal stem cells and their stem cell niche.

In vivo confocal microscopy and anterior segment optical coherence tomography are important developing diagnostic methods and may add a quantitative measure to the staging and follow-up of LSCD, as well as complementing impression cytology in the diagnosis of LSCD.

Definitive treatment involves transplant of healthy stem cells, and several strategies have been devised over the past two decades, many of which have developed from close collaboration between stem cell translational scientists and ophthalmologists.

In this review we analyse recent advances in the pathology, diagnosis, and treatment of LSCD.

\section{DIGITAL FEATURES}

This article is published with digital features to facilitate understanding of the article. To view digital features for this article go to https://doi. org/10.6084/m9.figshare.12957644.

\section{INTRODUCTION}

Limbal stem cells (LSCs) are the adult stem cells of the corneal epithelium; the transparent, multilayered, and avascular superficial layer of the cornea, the window at the front of the eye. They reside in an anatomically distinct stem cell niche within the limbus, which borders the circumference of the cornea (Fig. 1a, b) [1]. The unique paracrine, multicellular and physical properties of the LSC niche signal the LSCs to maintain their stem cell properties [2-4]. Reconstructed 3D optical coherence tomography reveals that the limbus architecture comprises a deep and complex network of crypts bordered by the palisades of Vogt (Fig. 1c) [5]. LSCs divide asymmetrically to produce transitamplifying cells in the peripheral cornea, which differentiate to produce mature corneal epithelium in the central cornea $[6,7]$. Differentiation is believed to be directed by a stromal stiffness gradient between the limbus and central cornea [3]. Any pathology which disrupts the native architecture of the LSC niche, or which directly destroys or damages LSCs, is a potential cause of limbal stem cell deficiency (LSCD) [8]. Herein we provide a critical appraisal of important, recent research in the pathology, epidemiology, and diagnosis of LSCD, and review recent advances in LSC transplantation for LSCD. An initial literature search was performed using MEDLINE by searching with the MEDLINE subject heading terms 'corneal diseases' OR 'corneal injuries' AND 'limbus corneae'. Relevant primary literature was also found in the references of these results. This article is based on previously conducted studies and does not contain any studies with human participants or animals performed by any of the authors.

LSCD is a rare, progressive, ultimately blinding corneal disease of wide-ranging etiology found throughout the world. Little epidemiological study of this disease has been performed; however, study of the principal causes of LSCD reveals its distribution and frequency. One study of LSCD incidence in New Zealand and Australia found only 14 cases of severe LSCD over 1 year [9]. Chemical injury is by far the most common cause of unilateral LSCD, responsible for around $66-75 \%$ of cases requiring LSC transplantation according to previous analysis of globally reported cases $[10,11]$. In a developing world setting, chemical injury was found to be responsible for $84 \%$ of all cases of unilateral LSCD [12]. A case series of all chemical eye injuries reporting to our casualty department demonstrated an incidence of 5.6 cases per 100,000 population. All four cases of Roper-Hall grade IV eye injuries in this case series developed total unilateral LSCD despite 

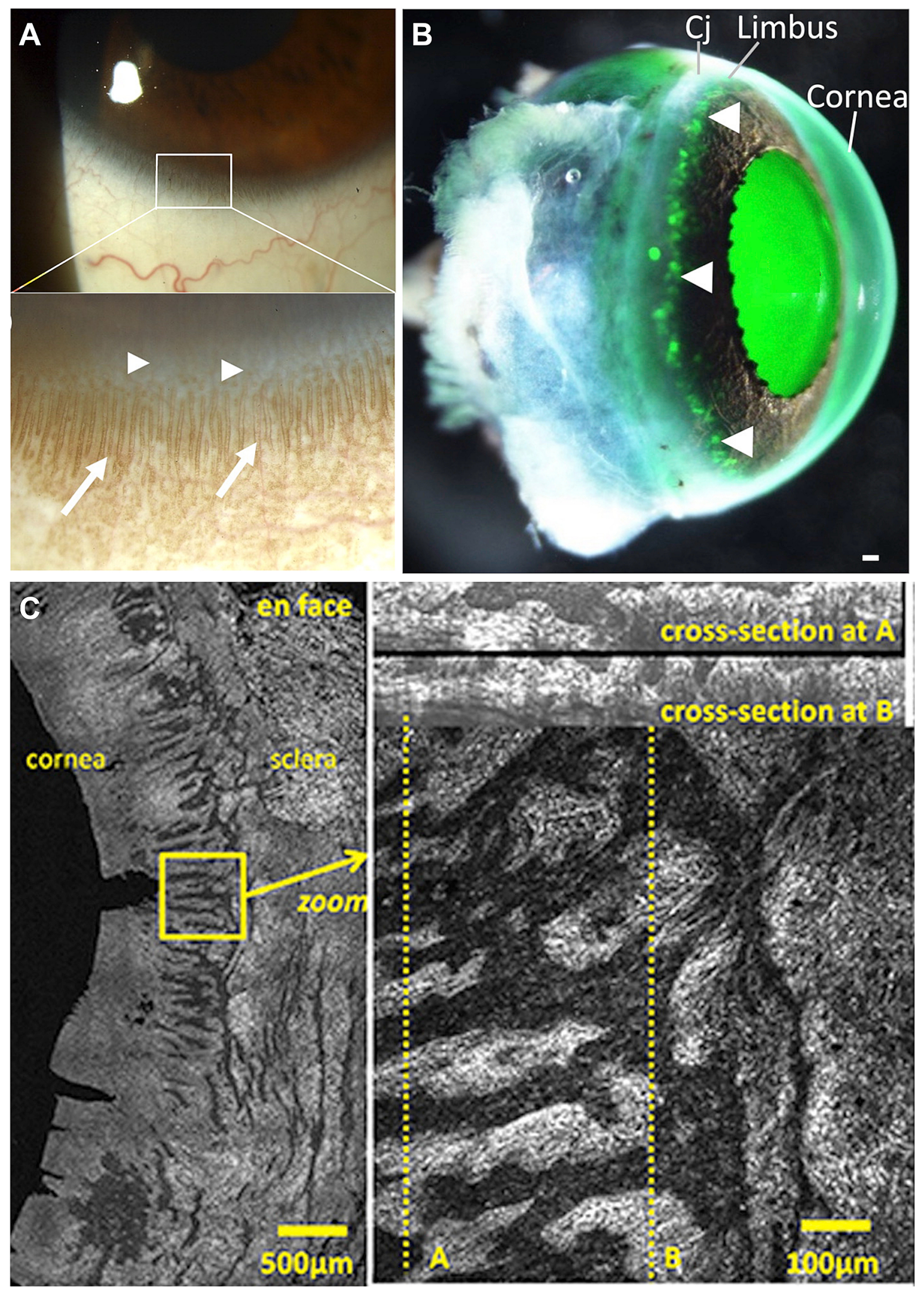
4 Fig. 1 The anatomy of the limbus. a Photographs of the human cornea, limbus, and conjunctiva. The limbus is located between the cornea and conjunctiva. Magnified area of limbus in a highly pigmented individual clearly showing the palisades of Vogt (arrows) which project onto the cornea (arrowheads). Adapted by permission from BMJ Publishing Group Limited (Miri et al. [45]). b An enucleated transgenic mouse eye showing the presence of cytokeratin 15-green fluorescent protein (GFP)-positive cells (arrowheads), indicating the position of putative limbal stem cells $(\mathrm{C} j=$ conjunctiva $)$. Reprinted from Nasser et al. [148] by permission from Elsevier. c Complex 3D structure of the human limbus revealed by anterior segment optical coherence tomography. En face image of the limbal palisades showing their radial architecture. An interconnecting circumferential crypt runs adjacent to the sclera (left image). A magnified portion of the limbus (right image) with cross section taken at $\mathbf{a}$ and $\mathbf{b}$ shown above. Reprinted from Grieve et al. (2015) [5] by permission from Elsevier

best management [13]. The reported incidence of severe chemical injury in the UK is 0.02 per 100,000 per annum, although this seems to be an underestimation when compared with our own data [14]. Stevens-Johnson syndrome/toxic epidermal necrolysis (SJS/TEN) is one of the leading causes of bilateral LSCD [12] and has an incidence of approximately 0.6 per 100,000 per annum [15]. Estimating the incidence of LSCD from its common causes gives around 240 new cases per annum in the UK [16].

In order of reducing frequency, patients suffering from severe LSCD complain of reduced vision, discomfort, pain and/or photophobia, redness, and tearing [17]. Patients usually experience symptoms for months to years before diagnosis [9]. Underlying conditions such as SJS/TEN often involve the conjunctiva and lids in addition to the cornea [18]. Individuals with LSCD are predisposed to potentially sight-threatening infectious keratitis [19].

In addition to chemical eye injuries and SJS/ TEN, many other causes of LSCD have been documented, and these are divided into acquired (further subdivided into immune- and non-immune-mediated) and hereditary [11]. Acquired non-immune LSCD is caused by direct injurious effects on the LSCs and/or their limbal niche. These causes include chemical $[12,20]$, thermal and radiation injury, infection [19], contact lens wear $[17,21,22]$, ocular neoplasm [23], and direct toxicity of topical anti-cancer drugs [23]. Acquired immune-related causes include SJS/TEN, mucous membrane pemphigoid, allergic eye disease, scleritis [24], and graft-versus-host disease [25]. Hereditary causes of LSCD are rare. Aniridia [26], epidermolysis bullosa [27], and xeroderma pigmentosum $[12,28]$ are well documented as causes of LSCD, although many other potential causes have been reported [11]. Idiopathic cases of LSCD have also been reported [29]. The many causes are reviewed more extensively elsewhere $[11,12]$.

\section{DIAGNOSIS OF LSCD: ADVANCES IN HIGH-RESOLUTION IN VIVO IMAGING}

Diagnosis of LSCD often relies on non-specific clinical signs, which are highly variable, in part due to the protean causes and variable nature of the disease. In one systematic review, diagnosis in $61 \%$ of published cases was based only on the clinical findings from slit-lamp biomicroscopy (unstable tear film, epithelial defects, loss of limbus features, whorl-like epitheliopathy, neovascularisation, fibrovascular pannus, and opaque epithelium arising from the limbus with late fluorescein staining) $[11,30]$. The relative presence or absence of these signs helps in the diagnosis and staging of LSCD (Fig. 2). However, in vivo laser scanning confocal microscopy (IVCM) and anterior segment optical coherence tomography (AS-OCT) facilitate greater accuracy in diagnosis and staging [31-35]. An international multidisciplinary working group on LSCD arrived at a staging system based on clinical features observed on biomicroscopy (Table 1) [11].

Impression cytology is considered the goldstandard investigation in the diagnosis of LSCD [11]. The technique involves obtaining a sample of the exposed epithelium on a piece of filter paper made of nitrocellulose acetate, cellulose acetate, or polytetrafluoroethylene, and analysing the adherent cells using 

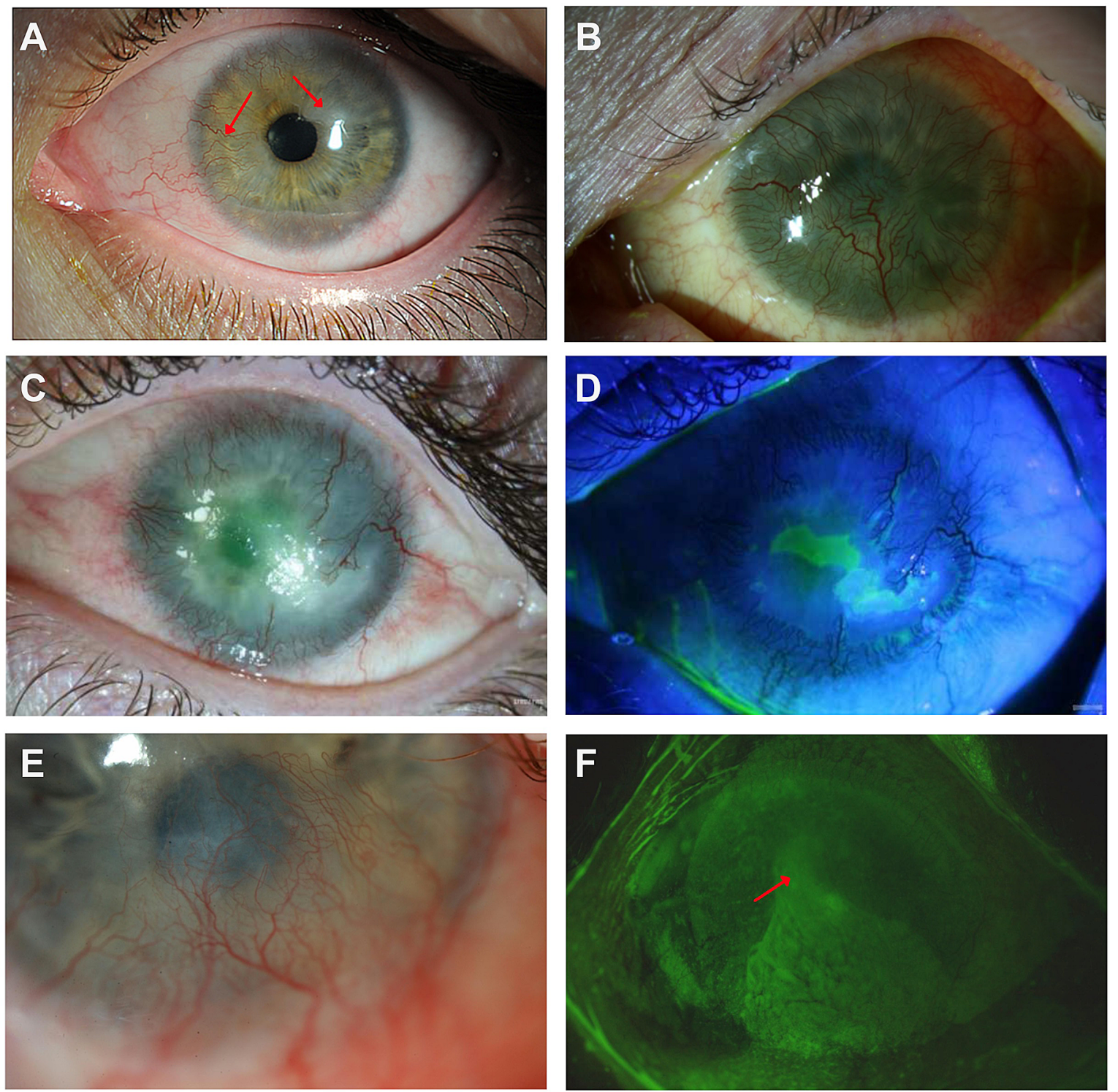

Fig. 2 Clinical signs of limbal stem cell deficiency as seen on slit-lamp biomicroscopy. a An example of stage IC LSCD following chemical injury. Conjunctivalisation is seen almost circumferentially (red arrows). There is sparing of the peripheral cornea at 3 o'clock and the visual axis. b An example of stage III LSCD with conjunctivalisation of the entire ocular surface following chemical injury. c An example of stage III LSCD following chemical injury, with conjunctivalisation of the entire cornea surface and stromal opacification affecting the visual axis. $\mathbf{d}$ The same eye from c seen under cobalt blue light following staining with $2 \%$

immunohistochemistry. Diagnosis relies on the detection of conjunctival or goblet cell markers

fluorescein. A persistent epithelial defect in the central cornea is brightly stained with fluorescein. e An eye with stage IIA LSCD following chemical injury showing a limited area of conjunctivalisation extending over the visual axis. f The same eye from e stained with $2 \%$ fluorescein and viewed under a cobalt blue light after $10 \mathrm{~min}$. There is delayed epithelial staining of the conjunctivalised portion of the cornea extending over the visual axis (arrow)

in the anatomical region of the cornea. These include cytokeratins CK7 $[36,37]$ and CK13 
Table 1 A new staging system for limbal stem cell deficiency based on slit-lamp findings

\begin{tabular}{|c|c|c|c|}
\hline Subdivision & $\begin{array}{c}\text { Stage } 1 \\
\text { Central } \\
5 \mathrm{~mm} \\
\text { spared }\end{array}$ & $\begin{array}{l}\text { Stage } 2 \\
\text { Central } 5 \mathrm{~mm} \\
\text { affected }\end{array}$ & $\begin{array}{l}\text { Stage } 3 \\
\text { Entire } \\
\text { cornea } \\
\text { affected }\end{array}$ \\
\hline A & $\begin{array}{l}\text { Less than } \\
50 \% \text { of } \\
\text { limbus } \\
\text { affected }\end{array}$ & $\begin{array}{r}\text { Less than } 50 \% \text { of } \\
\text { limbus affected }\end{array}$ & \\
\hline B & $\begin{array}{l}50 \% \text { or } \\
\text { more of } \\
\text { limbus } \\
\text { affected }\end{array}$ & $\begin{array}{c}50 \% \text { or more of } \\
\text { limbus affected } \\
\text { (but }<100 \%)\end{array}$ & \\
\hline $\mathrm{C}$ & $\begin{array}{l}100 \% \text { of } \\
\text { limbus } \\
\text { affected }\end{array}$ & & \\
\hline
\end{tabular}

This system was developed by an international working group [11]. Stages 1 and 2 have further subdivisions based on the proportion of limbus affected

[36, 37] for conjunctival cells, and MUC1 [38] and MUC5AC $[39,40]$ for goblet cells. Markers of corneal epithelium are detected with low sensitivity, and therefore the absence of these markers cannot rule out LSCD [11, 41-43]. Additionally, goblet cells may be absent in cicatrising disease such as SJS/TEN. Due to its low sensitivity and lack of spatial resolution, impression cytology cannot be used for staging [11]. IVCM and AS-OCT are promising diagnostic techniques which may help overcome some of the drawbacks of impression cytology, although until now their use has been mainly for qualitative assessment.

\section{In Vivo Laser Scanning Confocal Microscopy}

Diagnosis of LSCD by IVCM relies on signs produced by the abnormal invasion of conjunctival epithelium onto the cornea, and to a lesser extent the damage/destruction of the normal limbal architecture. Using IVCM, the normal architecture of the corneal epithelium and limbus is observed with axial and lateral resolution on the order of microns and at multiple depths [33]. In some patients with LSCD, the normal limbal architecture is lost, and the palisades of Vogt cannot be visualised. In the central cornea, epithelial cell contours are blurred, cells appear metaplastic, sub-basal fibrosis is seen, and the sub-basal epithelial cell density is reduced [44, 45] (Fig. 3). Low subbasal nerve plexus density has been shown to have $95.5 \%$ and $90.6 \%$ sensitivity and specificity for diagnosis of LSCD and is an early predictive sign for conjunctivalisation, preceding neovascularisation $[43,46]$. Goblet cells indicate the presence of conjunctival epithelium in the cornea (conjunctivalisation) and are a late sign of LSCD. These are hyperreflective cells, frequently arranged in rosettes; however, they are frequently not observed in patients with clinically obvious LSCD, and their absence therefore cannot rule out conjunctivalisation or LSCD [45]. Due to its cellular level of detail and multiple feature detection, it is possible that the sensitivity and specificity of IVCM for the diagnosis and staging of LSCD will surpass that of impression cytology [11]. Improving the utility of IVCM in the staging of LSCD and monitoring of disease progression or response to treatment will involve introducing quantitative methods for analysing IVCM images [47]. In turn, methods for quantitative analysis of IVCM images will allow the application of automated image analysis [48-51].

\section{Anterior Segment Optical Coherence Tomography}

Unlike IVCM, AS-OCT is a non-contact procedure [33]. Its strength lies in detecting precise changes in the 3D structure of the limbus (Fig. 1c) [5, 52], as scans may be taken and reconstructed in parallel, perpendicular, and en face planes relative to the limbus [33]. Loss of stromal undulations and normal epithelial thickening in the limbus can be detected early with AS-OCT, as can loss of clear transition between corneal epithelium and conjunctival epithelium [32]. Intra-operatively, AS-OCT has been used to visualise the cleavage plane 

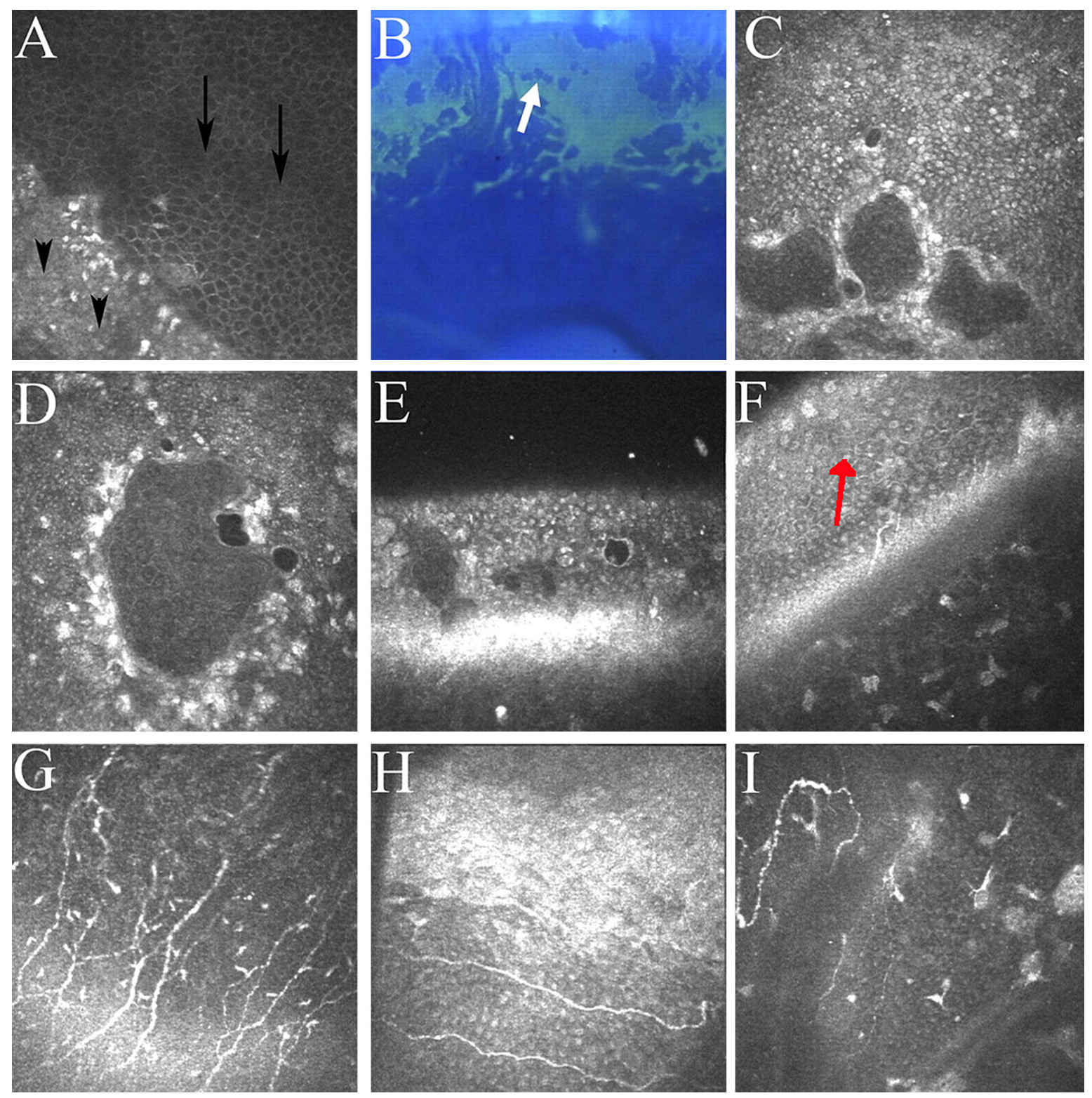

Fig. 3 In vivo confocal microscopy (IVCM) of the transition zone between conjunctivalised and normal corneal epithelium. Reprinted from Miri et al. (2012) [45] with permission from Elsevier. a Border between corneal epithelium (arrows) and conjunctivalised cornea (arrowheads). The wing cells of the corneal epithelium are dark, with bright, distinct cell borders. Conversely, the conjunctivalised epithelium has indistinct borders and is hyperreflective. b Delayed staining of conjunctivalised cornea under cobalt blue light after instillation of fluorescein 2\%. Four small islands of intact corneal epithelium are seen within a sector of conjunctivalisation (arrow). c The same three islands from b seen with (IVCM). $\mathbf{d}$ IVCM of an island of corneal epithelium, as seen in c, within the conjunctivalised cornea. Bright hyperreflective cells, possibly representing inflammatory cells, are seen surrounding the island. e An oblique view of a corneal island, seen extending as a dark column from Bowman's layer to the surface. (F) Metaplastic transformation of corneal epithelium adjacent to the conjunctivalised epithelium. These cells are larger than corneal epithelium and show hyperreflective nuclei (arrow). g Normal sub-basal corneal nerves seen in an area of normal corneal epithelium in an LSCD eye. $\mathbf{h}$ Sub-basal nerve running under an area of conjunctivalisation. i Abnormal tortuosity of sub-basal nerves seen under an area of conjunctivalisation 
between corneal pannus and stroma in order to precisely dissect the pannus without excessive corneal thinning [34]. Post-operatively, ASOCTA (angiography) can be used to objectively assess whether vessels are stromal or epithelial (and therefore assess regression of superficial vascularisation, indicating that the stem cell graft has been successful) $[53,54]$. The quantitative assessment power of AS-OCT images in LSCD patients has not yet been investigated to our knowledge. The availability of image analysis methods for AS-OCT and IVCM images will allow these modalities to move from adjunctive diagnostic tools to critical sources of clinical information on the LSCD disease stage and progression.

\section{TREATMENT OF LSCD}

\section{Medical Management}

Medical management aims to improve or maintain vision by reducing or preventing progression of corneal opacification and neovascularisation. Ocular surface discomfort is reduced by restoring the tear film and reducing ocular surface inflammation. Medical management is the mainstay treatment for stage I LSCD. Alternatively, medical management can play an important role in stabilising disease progression in advanced cases involving the central cornea (stage II and III) while the patient awaits definitive surgical treatment.

Initial management will involve prescribing artificial tears, lid hygiene, and warm compress to optimise meibomian gland function [55]. Importantly, all eye drops must be preservativefree. Contact lens wear can cause hypoxia, abnormal tear film distribution, mechanical trauma, and inflammation [17]. Therefore, cessation of contact lens wear is important. Shortor long-term topical corticosteroid treatment, topical cyclosporine, and antibiotics may also play a role [55]. Autologous and allogeneic serum drops have been effective in some patients as well [56-58]. One patient with stage II/III LSCD showed near-complete regression of corneal neovascularisation and substantial improvement in vision after daily treatment with bevacizumab delivered via prosthetic replacement of the ocular surface ecosystem (PROSE) [59].

Unfortunately, there is no consensus on the most appropriate medical treatment regime for LSCD. The relapse rate for medically treated LSCD is also not clear.

\section{Tissue Transplant Techniques: Conjunctival-Limbal and Keratolimbal Grafts}

When the resident population of LSCs is insufficient to replenish the corneal epithelium and the visual axis becomes involved, surgical treatment is indicated [60]. We will begin the discussion of the surgical management of LSCD with the traditional tissue transplant techniques which aim to repopulate the corneal surface with LSCs. These are still the most widely used surgical treatments for LSCD. Surgical procedures for LSCD are classified by the source of stem cells (e.g. autologous, allogeneic) and type of stem cell graft (e.g. limbal, oral mucosa, hair follicle, among others) and the use of ex vivo expansion of stem cells in culture [61]. For allogeneic grafts, immunologic rejection continues to be one of the main causes of graft failure [62, 63], and grafts are thought to be at high risk of rejection and consequent failure even 3 years after transplantation [63]. For a review of the specific complications of these procedures see Yin et al. [64]. Penetrating keratoplasty (PKP) is frequently undertaken as a second procedure following LSC transplantation in order to replace deep scarred stroma, with the ultimate aim of restoring sight [65-67].

For patients with unilateral LSCD, the healthy contralateral eye can provide a donor site for a free limbus tissue graft to the injured other eye. The conjunctival limbal autograft (CLAU) is the most commonly performed procedure in cases of unilateral LSCD with a healthy contralateral eye [60, 68-70]. Typically, two conjunctival-limbal sections of 2 clock hours each are harvested from the healthy other eye (Fig. 2). A possibly devastating complication is the development of LSCD in the healthy donor eye [71]. However, a retrospective analysis of 45 
patients found no evidence of LSCD in the donor eyes, and furthermore the donor eyes maintained visual acuity of $-0.05 \log$ MAR after a mean follow-up of 48 months, indicating the rate of occurrence of donor eye LSCD is likely low [67]. Despite the low risk of inducing LSCD, biopsy of the only seeing eye is not an option for many patients with LSCD.

For severely damaged ocular surfaces with insufficient conjunctiva and symblepharon, a combined CLAU and living related-conjunctival limbal allograft (lr-CLAL) procedure has been described which maximises the amount of transplanted conjunctiva [72]. This procedure also has the advantage of restoring double the circumference of the limbus of a normal CLAU, increasing the number of LSCs and the barrier to conjunctivalisation. Artificial keratoprosthesis is an option for patients with repeat graft failure. This may be secondary to severe lid disease resulting from chemical injury or SJS/ TEN [73].

Keratolimbal allograft (KLAL) utilises cadaveric peripheral cornea and limbus obtained from eye banks, and therefore can be utilised in the case of bilateral LSCD, or when the patient with unilateral disease is unwilling to use the healthy other eye as a donor and no living relative is available or there is no human leukocyte antigen (HLA) match. It is suited to cases where the conjunctiva is relatively intact. For cases of bilateral LSCD, where the conjunctiva requires reconstruction, the Cincinnati procedure may be used: combined lr-CLAL and KLAL with systemic immunosuppression [74]. With this procedure a $360^{\circ}$ limbus is restored, but there is a high risk of graft rejection due to the use of multiple allogeneic tissues, particularly the KLAL, which is often not HLA-matched for practical reasons [75].

Despite the low risk of donor eye LSCD [67], the amount of limbal epithelium that can be safely harvested from a donor eye is limited to about 4 clock hours in total. If additional limbus is required as a barrier to conjunctivalisation of the cornea, then this can be sourced from living relatives, as in the combined CLAU/ lr-CLAL procedure described above, or if a living relative is not available, then the modified Cincinnati procedure can be performed: combined CLAU and KLAL [75]. This procedure restores $360^{\circ}$ of limbus, but systemic immunosuppression is required.

The need for systemic immunosuppression, which is itself associated with morbidity and additional monitoring requirements, and the tendency for immunologic rejection in allografts has led to the development of cell therapies, which we will discuss in the next section.

\section{Cultivated Limbal Epithelial Transplant (CLET)}

An ideal surgical treatment should theoretically aim to establish a population of stem cells which can survive over the long term and renew the corneal epithelium. Ideally, it should also restore a suitable stem cell niche for these stem cells to survive within, although this goal is probably not attained by current therapies. Regardless of the procedure undertaken, the graft should contain a minimal population of stem cells. The autologous tissue-engineered product Holoclar defines a minimum number of p63 positive cells (representing holoclones) in the donor tissue required for successful regeneration of the host corneal surface [76-78]. The ideal therapy need not transplant LSCs per se, so long as transplanted stem cells can generate a transparent epithelium [79].

While CLAU and lr-CLAU require a substantial graft from a healthy eye, CLET requires only a small graft from a healthy eye (approximately $2 \mathrm{~mm}^{2}$ ) [80, 81]. Typically, limbal epithelial tissue is expanded as an intact explant, but biopsies may be digested to yield suspension cultures, which have also been used successfully [82]. After approximately a 2-week culture period on a carrier scaffold, most commonly human amniotic membrane (HAM) or fibrin, the stem cell construct, are then transplanted onto the ocular surface [80, 81, 83, 84]. A full superficial keratectomy which removes all conjunctivalised tissue is performed to prepare the ocular surface to receive the ex vivo-engineered stem cell construct (Fig. 4a). The Holoclar system includes a cryopreservation step which provides time for sample testing and synchronising sample preparation with the planned 

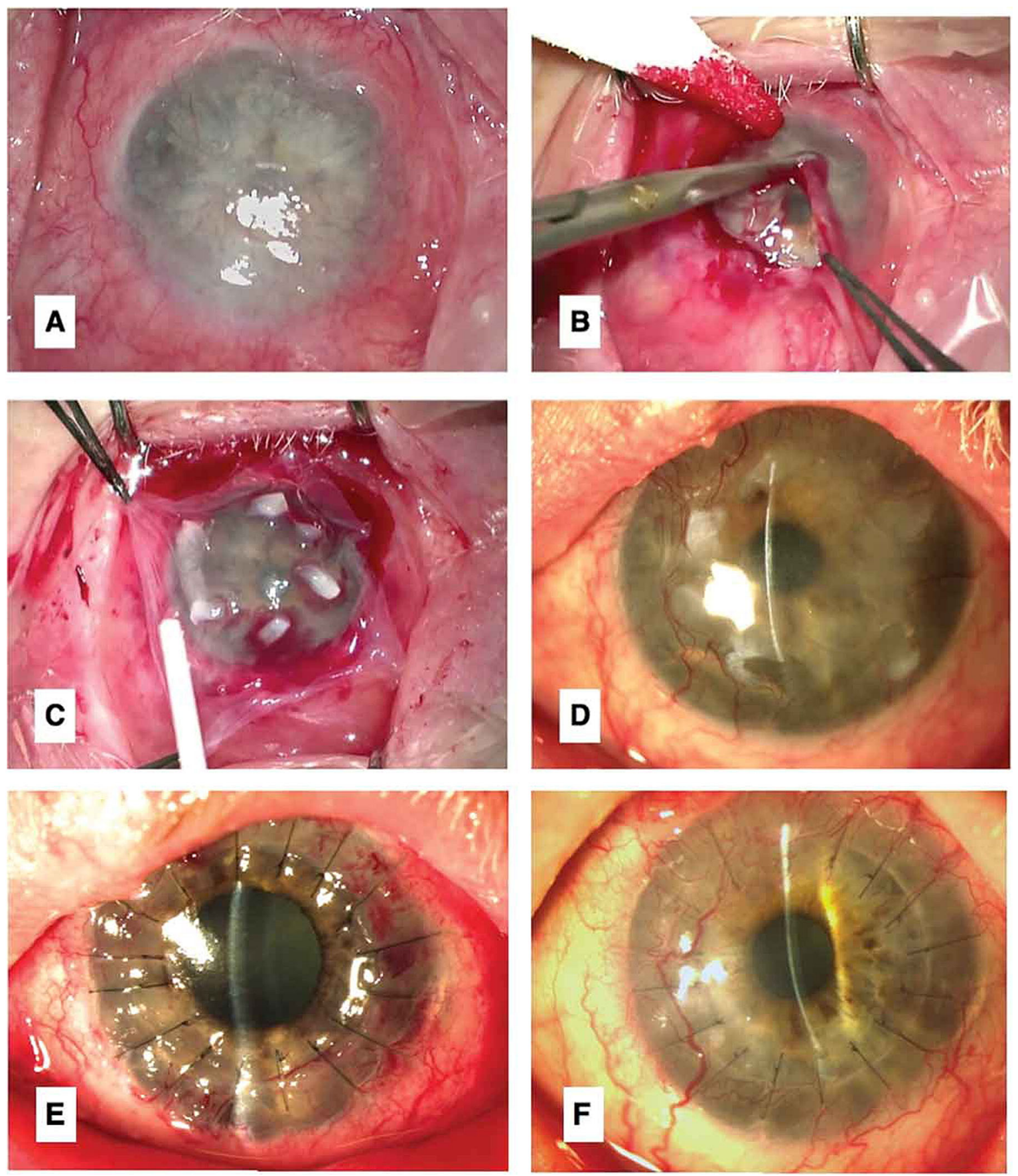
4Fig. 4 Stages of simple limbal epithelial stem cell transplantation (SLET) for LSCD. Reprinted from Vasquez-Perez and Nanavaty [23] by permission of Taylor \& Francis Ltd, https://www.tandfonline.com. a An eye with total conjunctivalisation of the corneal surface seen preoperatively. b A 360-degree superficial keratectomy is performed to remove fibrovascular pannus. c In this operation, simple limbal epithelial transplant (SLET) is being performed. Donor limbal tissue is divided into multiple smaller pieces which are distributed over the corneal surface and secured with fibrin glue. Human amniotic membrane is placed over the pieces of donor limbus. $\mathbf{d}$ The corneal surface seen 3 months post-op, with reduced conjunctivalisation and improved central corneal clarity. e A penetrating keratoplasty was performed 6 months post-SLET. Penetrating keratoplasties are commonly performed after limbal stem cell transplant procedures to restore central corneal clarity and therefore vision. f Six months after penetrating keratoplasty: some peripheral neovascularisation is seen.

date of surgery [85]. Air-lifting may be used during the ex vivo culturing period to induce stratification of cultured epithelium, and involves reducing the culture medium volume in order to expose the epithelium to atmospheric air [86]. Our group reported the successful clinical implementation of xenobioticfree conditions for the ex vivo expansion of limbal epithelium on HAM [81]. Xenobioticfree conditions are now widely used to minimise the risk of disease transfer or immune reaction $[10,87,88]$. CLET is more accurately described as ex vivo cultivated limbal autograft/ allograft (EVCAU/EVCAL, respectively) [61].

Grafts may be autologous or allogeneic in origin. In theory, CLET minimises the exposure to non-self antigens in the case of allogeneic grafts. As the grafts are expanded from a small biopsy, they presumably contain very low numbers of antigen-presenting Langerhans cells, melanocytes, and vascular endothelium found in the normal LSC niche [4]. Two systematic reviews investigating the outcomes of CLET found no significant difference in treatment success or visual improvement after autologous and allogeneic CLET [10, 89], although a phase II clinical trial reported a high risk of graft rejection and subsequent failure after allogeneic CLET [90].

In 2015, Holoclar became the first stem cellbased medicine to achieve market authorisation through the European Medicines Agency. This landmark achievement makes CLET widely available and introduces a rigorous, standardised, and centralised manufacturing system throughout Europe [85].

The fate of transplanted donor LSCs on the ocular surface is currently unknown [91]. There are several possible mechanisms of action: (1) donor LSCs migrate to and regenerate the host LSC niche, before regenerating the corneal epithelium; (2) donor LSCs create a new pseudoniche outside of the host LSC niche, and then regenerate the corneal epithelium; (3) donor LSCs stimulate remaining host LSC regeneration of the corneal epithelium through paracrine or direct physical interaction; and (4) the host epithelium is regenerated from donor transit-amplifying cells, but not true LSCs, and therefore the graft longevity is potentially limited. Post-operative IVCM shows that CLET does not appear to regenerate the original host limbal architecture [92].

CLET is a relatively new procedure, and therefore there is little data showing long-term (> 5 years) graft survival let alone cure of LSCD, although outcomes in the short term (mean follow-up being less than 3 years for the vast majority of reported studies) have been very good, with around $67 \%$ success at final followup $[10,89]$. Behaegal et al. found a drop-off in best-corrected visual acuity and success rate between short (2-year)- and long-term (7-year)follow-up in a cohort of mostly autologous grafts [88]. While anatomical success was only $46 \%$ in the short term, it dropped to $23 \%$ in the long term. Failure was defined as 'recurrent epithelial defects and/or superficial corneal neovascularisation or conjunctivalisation encroaching on the central $4 \mathrm{~mm}$ of the cornea' [88]. Borderie et al. reported a phase II trial comparing autologous and allogeneic CLET with a mean follow-up of 6 years in 14 patients with histologically confirmed LSCD [90]. They found a high rate of adverse events in the allogeneic group, including raised intraocular pressure (IOP), cataract requiring surgery, corneal 
perforation, and immunologic graft rejection. In the autologous group, the only adverse events were two instances of epithelial defects treated topically, which were both seen in the same eye. The autologous and allogeneic groups are, however, non-comparable due to the differing indications for autologous or allogeneic CLET, and furthermore failure criteria are based on subjective clinical findings. Importantly, even the autologous CLET group found a drop in estimated graft survival, from $100 \%$ at 3 years to $71 \%$ at 5 years. Although further data will be needed to verify the long-term curative rate for CLET, the findings of Behaegal et al. and Borderie et al. raise concerns that graft longevity may be limited. This lack of a supporting and healthy LSC niche may limit the long-term viability of donor LSCs $[88,90]$.

One solution to the lack of niche protection for transplanted LSCs may lie in bioengineering approaches which aim to synthesise artificial LSC niches with equivalent mechanical properties and adhesive surfaces [93, 94]. Theoretically, donor LSCs could be cultured on such substrate before transplantation of cells and scaffold, possibly increasing long-term LSC survival. Ideally, vascular endothelial cells, melanocytes, and other cells normally found in the LSC niche would be able to repopulate this synthetic niche, as was previously observed in collagen-based synthetic corneal implants in rabbits $[4,95]$.

Long-term storage of cultivated LSCs may allow re-grafting in cases of relapse, without the need for further biopsy. Hence, cryopreservation of cultivated LSCs can potentially allow their indefinite storage for re-graft and transport from centralised laboratories [85, 96, 97].

\section{Simple Limbal Epithelial Transplant (SLET)}

SLET is a relatively new procedure, described by Sangwan et al. [98]. It involves taking a small biopsy $(2 \times 2 \mathrm{~mm})$ from a healthy limbus, dividing this biopsy into 8-10 pieces, and evenly distributing these pieces on HAM before transplantation to the surgically prepared ocular surface with LSCD (Fig. 4). The fluorescein staining pattern seen after transplant suggests that new epithelium grows outwards from the small limbal grafts, coalescing and covering the corneal surface within 2 weeks [99]. The advantages of this procedure are that only a small biopsy is required, much less than CLAU and the same as CLET, while laboratory facilities are not required for ex vivo expansion of the limbal biopsy. Furthermore, the surgery is relatively simple [98]. A multicentre study of 68 cases found a completely clear cornea in $80 \%$ of cases at a median follow-up of 12 months, although immune causes of LSCD were excluded from this study [100]. Symblepharon has been noted as an important negative prognostic factor for treatment success $[100,101]$.

However, like CLET, SLET does not solve the limbus regeneration problem: an LSC niche is not restored, and therefore it is not clear how graft longevity will be maintained [88]. The opaque limbal biopsies are no longer seen on slit-lamp biomicroscopy at 1-2 months postoperatively, indicating that the limbal connective tissue is broken down or remodeled in vivo $[98,99]$. SLET places multiple colony-forming centres over the corneal surface, altering the natural relationship between LSCs and differentiated epithelium and their interaction with the LSC niche. It is not clear how a corneal epithelium would be maintained long after PKP, which is often required, which would presumably remove many of the colony-forming centres on the corneal surface (Fig. 4e). Short-term results in a group of seven patients (mean follow-up of 15 months) show that most PKPs survive; however, it is not clear what visual improvement, if any, PKP offered in this cohort, and many of the patients had poor visual acuity at final follow-up [65].

\section{Cultivated Oral Mucosa Epithelia Transplant (COMET)}

For cases of bilateral LSCD, which may result from systemic diseases such as SJS/TEN, hereditary disorders, or bilateral chemical injuries, the source of LSCs is limited to allografts (e.g. lrCLAL, KLAL). The use of allogeneic tissue is associated with a high risk of graft rejection and 
also requires patients to undergo long-term systemic immunosuppressive therapy, which has prompted clinicians to search for alternative sources of autologous cells [102]. Furthermore, in certain patients, systemic immunosuppression is contraindicated and therefore allografts are not an option. Allogeneic limbal tissue also may not be available depending on location [103]. Cultured oral mucosal epithelial transplantation (COMET), as described by Nakamura et al. in 2003, provides another autologous source of epithelium to reconstitute the corneal epithelial surface [104-106]. COMET is also known as ex vivo cultivated oral mucosal autograft (EVOMAU) [61].

The oral mucosa is a stratified epithelial lining and has favorable characteristics which make it a suitable substitute for LSCs in cases of bilateral LSCD: it is semi-transparent, it is easily accessible surgically, it has a high regenerative capacity, it does not readily keratinise, and the donor site generally does not scar [79, 104-106]. Stem cell-like cells are present basally in mucosal epithelial biopsies. Phenotypically, they are small, with a large nuclear-cytoplasmic ratio, and express Ki67 and p63 [79]. A basal population of p63-expressing cells persists in COMETtreated corneas, and the corneal epithelium is thicker [107]. While 18-20 layers are present initially, this reduces with ex vivo cultivation [86]. Histological analysis of tissue-specific cytokeratin in corneal buttons obtained from PKP performed 14 months post-COMET suggest long-term persistence of oral mucosal cells and their progenitors in the central cornea, although some eyes show a mixed corneal and oral epithelium [86, 107, 108].

Typically, a small biopsy (2-10 $\mathrm{mm}$ diameter have been reported) of oral mucosa without subcutaneous fat is harvested from the patient's mouth, often inside the cheek $[79,102,109,110]$. Like CLET, this biopsy may be expanded as an intact sheet or in a suspension culture $[79,102]$. Similarly, previous methods have relied on the use of xenobiotics, most critically co-culture with murine 3T3 fibroblasts and cell medium supplementation with fetal calf serum (FCS) [79]. To minimise the risk of acute graft rejection and disease transfer, our laboratory and others have attempted to replace these 3T3s and FCS with xenobiotic-free conditions [79, 102]. For example, we previously developed Good Manufacturing Practice (GMP)-compliant conditions for the ex vivo cultivation of oral mucosa in explant and suspension culture by replacing 3T3 feeders with HAM and FCS with autologous serum. We then demonstrated their successful clinical application in two patients with bilateral LSCD [79].

Choe et al. bypassed the need for a two-stage procedure and expensive culture facilities by directly transplanting a circumferentially trephined labial oral mucosa biopsy harvested from the inferior lip. The surgeons harvested a 14-mm-diameter crescent-shaped biopsy to cover the limbus and peripheral cornea in five patients and found improved visual acuity in all patients and improved epithelial defects in $4 / 5$ patients at 4 months post-operatively [111]. This procedure may become an option in the future once the stability of the improvements is determined.

COMET shows improvement in conjunctivalisation, corneal opacification, neovascularisation, and symblepharon in the majority of patients [102, 105, 106, 109, 110, 112]. Improved visual acuity which can be sustained over months and years can be achieved with COMET in patients with SJS/TEN, although the results are poorer in patients with ocular cicatricial pemphigoid. As with LSC transplant, PKP may also be required as a second procedure to replace deep stromal fibrosis [102].

Persistent peripheral corneal neovascularisation is reported in most patients after COMET $[106,110]$. An AS-OCTA study of neovascularisation post-COMET revealed that over $83 \%$ of examined corneal quadrants showed epithelial neovascularisation, indicating probable conjunctivalisation [53]. This conjunctivalisation advanced centrally, producing increased discomfort and vision loss; however, we have not found studies with a mean follow-up of longer than 4 years, and therefore the long-term success of COMET and need for repeat procedure is unknown. Long-term follow up shows that although best corrected visual acuity is improved in patients with poor vision, the level of vision attained remains low [113]. This may be in part due to the incomplete differentiation 
of oral mucosa into a corneal epithelial phenotype [114].

It has been suggested that the peripheral neovascularisation seen post-COMET is due to the differential expression of pro- and anti-angiogenic factors between normal corneal epithelium and oral mucosal epithelium. Soluble FMS-like tyrosine kinase-1 (sFlt-1), tissue inhibitor of metalloproteinase- 3 (TIMP-3) and thrombospondin-1 (TSP-1) were found to be reduced in corneal specimens from patients who had undergone COMET [115]. Subsequent work has co-cultured LSCs with cells derived from the LSC niche (including mesenchymal and limbal epithelial cells) as a feeder layer and found higher expression of sFlt-1 and lower levels of basic fibroblast growth factor (FGF; a pro-angiogenic factor) as compared to $3 \mathrm{~T} 3 \mathrm{co}-$ culture. Transplant of the cultured epithelium in a rabbit model of total LSCD restored corneal clarity without neovascularisation although further work is needed to examine whether this strategy is effective in reducing peripheral neovascularisation as compared to $3 \mathrm{~T} 3$ co-culture or xenobiotic-free methods [116].

\section{Other Sources of Stem Cells: Hair Follicles, Dental Pulp, and Induced Pluripotent Stem Cells}

In the search for alternative tissue stem cells which may replace allogeneic tissue grafts, autologous hair follicle stem cells and dental pulp stem cells have been identified. Corneal epithelial basal cells, under the influence of Wnt and noggin signalling, can transdifferentiate into epidermis and mature hair [117]. Hair follicles are the main source of epidermal stem cells [118]. The regeneration of both the corneal epithelium and hair follicles is dependent upon cytokeratin-14-expressing stem cells residing in specific stem cell niches. In the case of hair follicles, this niche is the outer root sheath [119]. It follows that mimicking the LSC niche environment with limbal fibroblast-conditioned media and laminin-5 induces a corneal epithelial phenotype in stem cells isolated from hair follicles, with the expression of PAX6 and cytokeratin-12 [120]. Therapeutic potential was demonstrated in a murine LSCD model, with reduction in neovascularisation and conjunctivalisation and improved barrier function [121]. Hair follicle stem cells are an attractive option in corneal surface reconstruction due to their ubiquity, easy access, and autologous nature; however, little work beyond these initial animal studies has taken place.

Dental pulp cells extracted from the vascular dental pulp of human molars express markers of mesenchymal and embryonic stem cells $[122,123]$. ABCG2, integrin- $\beta 1$, vimentin, p63, connexin 43, and cytokeratins 3 and 12 are also expressed as putative LSC markers [124]. Transplantation of autologous dental pulp cell sheets into a rabbit model of alkaline-induced LSCD was found to cause differentiation into a corneal epithelial-like phenotype and improved corneal neovascularisation and conjunctivalisation [122, 124]. They can also be differentiated towards a corneal stromal keratocyte phenotype and generate corneal stroma-like connective tissue when cultured on scaffolds in vitro [123]. Amniotic membrane and soft contact lenses have been characterised as delivery vehicles $[125,126]$; however, to our knowledge, in vivo human work has not been published.

The differentiation of embryonic stem cells (ESCs) to corneal epithelium presents an opportunity to develop potentially limitless amounts of corneal epithelium in vitro for transplantation purposes. ESCs have been differentiated into a corneal epithelial progenitor phenotype on type-IV collagen, a component of the corneal epithelial basement membrane. Approximately $20 \%$ of these cells expressed PAX6, a marker of early eye development, and cytokeratin-12, a corneal-specific marker [127]. A higher proportion of corneal epithelium-like cells can be obtained through PAX6 cDNA transfection [128]. These cells also express p63, indicating an LSC phenotype rather than differentiated corneal epithelial phenotype [128]. Both cells demonstrated short-term survival after transplantation to a murine model of total LSCD [127-129]. ES-cell-derived corneal epithelium and endothelium-like cells cultured on opposite sides of a porcine corneal matrix were transplanted as a full-thickness cornea 
substitute in rabbits, remaining intact and transparent up to week 8 post-op, with evidence of normal deturgescence [130].

The development of a transplantable epithelial sheet from human induced pluripotent stem cells (iPSCs) is an important goal in corneal translational science. Such technology would afford an unlimited supply of autologous LSCs and corneal epithelium [131]. LSC-like cells have been generated from human iPSCs by inhibiting TGF- $\beta$ and Wnt signalling while activating FGF signalling [132]. This combination of factors allowed the generation of homogeneous LSC-like cells which expressed p63 and other putative LSC markers. These cells were capable of differentiation towards a mature corneal epithelial phenotype [132, 133] and can be cultured on transplantable bioengineered sheets [93]. Other methods have looked at the direct transdifferentiation of fibroblasts to LSC-like cells (thus avoiding potentially teratogenic iPSCs) [134] and the development of corneal organoids [135]. Further translational research has identified techniques for purifying the LSC-like population of cells generated from iPSCs [136]. Hayashi et al. recapitulated ocular development in 2D by creating a 'SEAM' (selfformed ectodermal autonomous multi-zone), which included neuroectodermal, neural crest, and ectodermal progenitors [137, 138]. Ectodermal progenitors isolated by fluorescence-activated cell sorting were able to be expanded ex vivo and rescue a rabbit model of LSCD [137].

Mesenchymal stem cells (MSCs) are potential candidates for regeneration of the host niche. MSCs are natural residents of the LSC niche, interacting physically and in a paracrine fashion with LSCs [139]. They have immune-modulatory properties and have been shown to reduce neovascularisation, stromal opacification, inflammation, and corneal oedema in animal models of LSCD secondary to chemical or mechanical injury [140]. Among the several paracrine factors produced by MSCs, tumour necrosis factor- $\alpha$-stimulated gene 6 (TSG-6) has been shown to be necessary for MSCs to deliver their anti-inflammatory effects [141]. An inhuman, proof-of-concept, randomised, doubleblind controlled trial demonstrated possible equivalency of allogeneic MSC therapy and allogeneic CLET in the treatment of bilateral stage II/III LSCD [142]. Primary end points included corneal epithelial opacification, integrity (presence of persistent defects), and cell morphology (as measured by IVCM). For extensive reviews of their role in the LSC niche and the developing applications of MSCs in corneal regenerative medicine, see Yazdanpanah et al. [143] and Al-Jaibaji et al. [140], respectively.

\section{DISCUSSION AND FUTURE PERSPECTIVES}

The first CLAU procedure was performed by Kenyon and Tseng [60]. Ophthalmologists can now offer several surgical treatments to patients with LSCD, with the aim of replacing their scarred ocular surface with a transparent and smooth epithelium. The next investigative steps should answer the following questions: How similar are the ex vivo expanded limbal epithelial cells to their counterparts in vivo? What is the fate of transplanted LSCs on the host ocular surface? What is the mechanism by which transplanted LSC-containing tissues improve ocular surface conditions? What is the role of inflammation and corneal nerve function on the survival and differentiation capacity of transplanted LSCs? What happens to the limbal niche and how best to repair it? Lineage tracing of cytokeratin-14 expressing corneal progenitors in confetti mice has demonstrated their centripetal migration in the healthy and injured mouse cornea [7]. Further work used transplanted grafts from confetti mice (with labeled cytokeratin-14) in LSCD wild-type mice. This work showed evidence of initial survival of transplanted LSCs with preference for the peripheral cornea. However, some of these LSCs migrated to the central cornea and dedifferentiated. The number of putative LSCs decreased in the weeks following transplantation, and the most successful grafts were those which started with the most putative LSCs [144].

Research from multiple disciplines has demonstrated that the specific physical properties and paracrine milieu of the stem cell niche maintain the stem cell phenotype, including 
the capacity for unlimited self-renewal [3, 4, 145-147]. Furthermore, it is now apparent that following total ablation of the limbus, committed corneal epithelial cells can migrate to the limbus and dedifferentiate to putative LSCs. This dedifferentiation is prevented by mechanical destruction of the limbal niche [148].

Considering the above data, it seems unlikely that transplanted LSCs would retain their stem cell properties outside of a suitable niche. Long-term ( $>5$ year) graft survival data is beginning to show us the limits of CLAU, CLET, SLET, COMET, and other therapies. Future work may seek to create the conditions for LSC regeneration on the ocular surface, but outside of the limbus, to promote long-term graft survival, possibly through the use of topical growth factors [147].

Alternatively, future work may aim to create a transplantable, tissue-engineered stem cell niche. This will also require new surgical approaches, and the neo-niche will need to be integrated into the ocular surface and support the long-term survival of the transplanted stem cells. The efficacy of transplanted HAM in partial LSCD suggests that it recruits host LSCs (and possibly circulating hematopoietic stem cells) and may itself serve as a surrogate LSC niche [4]. Work from our lab has shown that decellularised, $\gamma$-irradiated HAM may enhance the expansion of LSCs ex vivo while reducing batch variation and risk of disease transfer [149].

A third strategy may aim to regenerate the architecture of the original host niche. In this regard, the co-transplant of limbal niche cells may help to rejuvenate the niche extracellular matrix (ECM) and paracrine milieu. The use of topical collagenase has been shown to restore the mechanical properties of the chemically burned limbus, and thereby restore its capacity to support the LSC phenotype [3]. This work raises the possibility of cell-free treatments for LSCD which aim to restore the LSC niche.

COMET is a promising strategy for regeneration of the ocular surface, not least because it is an almost universally available autologous tissue and avoids the harvesting of precious limbal tissue from a healthy eye. Long-term follow-up data is needed to verify the capacity of the graft to self-renew. If oral mucosa stem cells persist on the ocular surface, then a promising strategy to promote their longevity would be to create supportive conditions on the ocular surface, for example transplant on artificial scaffolds of appropriate stiffness and with suitable cell adhesion properties [150]. Future work must also address the problem of peripheral neovascularisation of COMET grafts.

Induced pluripotent stem cells reprogrammed from patient skin biopsies may provide a population of autologous corneal epithelial cells rich in LSCs [93, 133, 137], which could be seeded onto biological scaffolds which mimic the stem cell niche [93], or cocultured with MSCs [116].

In summary, this review has shown that the treatment of LSCD is an excellent example of how breakthroughs in basic science can be quickly translated to the operating theatre, and that multiple avenues exist for the future development of treatments for LSCD.

\section{ACKNOWLEDGEMENTS}

Funding. No funding or sponsorship was received for this study or publication of this article.

Authorship. All named authors meet the International Committee of Medical Journal Editors (ICMJE) criteria for authorship for this manuscript, take responsibility for the integrity of the work, and have given final approval to the version to be published.

Disclosures. Ali E. Ghareeb, Majlinda Lako, and Francisco C. Figueiredo have nothing to disclose.

Compliance with Ethics Guidelines. This article is based on previously conducted studies and does not contain any studies with human participants or animals performed by any of the authors. 
Data Availability. Data sharing is not applicable to this article as no data sets were generated or analysed during the current study.

Open Access. This article is licensed under a Creative Commons Attribution-NonCommercial 4.0 International License, which permits any non-commercial use, sharing, adaptation, distribution and reproduction in any medium or format, as long as you give appropriate credit to the original author(s) and the source, provide a link to the Creative Commons licence, and indicate if changes were made. The images or other third party material in this article are included in the article's Creative Commons licence, unless indicated otherwise in a credit line to the material. If material is not included in the article's Creative Commons licence and your intended use is not permitted by statutory regulation or exceeds the permitted use, you will need to obtain permission directly from the copyright holder. To view a copy of this licence, visit http://creativecommons.org/licenses/bync/4.0/.

\section{REFERENCES}

1. Schermer A, Galvin S, Sun TT. Differentiation-related expression of a major $64 \mathrm{~K}$ corneal keratin in vivo and in culture suggests limbal location of corneal epithelial stem cells. J Cell Biol. 1986;103: 49-62.

2. Ahmad S, Stewart R, Yung S, Kolli S, Armstrong L, Stojkovic M, Figueiredo F, Lako M. Differentiation of human embryonic stem cells into corneal epithelial-like cells by in vitro replication of the corneal epithelial stem cell niche. Stem Cells. 2007;25:1145-55.

3. Gouveia RM, Lepert G, Gupta S, Mohan RR, Paterson C, Connon CJ. Assessment of corneal substrate biomechanics and its effect on epithelial stem cell maintenance and differentiation. Nat Commun. 2019;10:1-17.

4. Li W, Hayashida Y, Chen Y-T, Tseng SC. Niche regulation of corneal epithelial stem cells at the limbus. Cell Res. 2007;17:26-36.

5. Grieve K, Ghoubay D, Georgeon C, Thouvenin O, Bouheraoua N, Paques M, Borderie VM. Three- dimensional structure of the mammalian limbal stem cell niche. Exp Eye Res. 2015;140:75-84.

6. Thoft RA, Friend J. The X, Y, Z hypothesis of corneal epithelial maintenance. Investig Ophthalmol Vis Sci. 1983;24:1442-3.

7. Amitai-Lange A, Altshuler A, Bubley J, Dbayat N, Tiosano B, Shalom-Feuerstein R. Lineage tracing of stem and progenitor cells of the murine corneal epithelium. Stem Cells. 2015;33:230-9.

8. Kruse FE, Chen JJ, Tsai RJ, Tseng SC. Conjunctival transdifferentiation is due to the incomplete removal of limbal basal epithelium. Investig Ophthalmol Vis Sci. 1990;31:1903-13.

9. Bobba S, Di Girolamo N, Mills R, Daniell M, Chan E, Harkin DG, Cronin BG, Crawford G, McGhee C, Watson S. Nature and incidence of severe limbal stem cell deficiency in Australia and New Zealand. Clin Exp Ophthalmol. 2017;45:174-81.

10. Zhao Y, Ma L. Systematic review and meta-analysis on transplantation of ex vivo cultivated limbal epithelial stem cell on amniotic membrane in limbal stem cell deficiency. Cornea. 2015;34:592-600.

11. Deng SX, Borderie V, Chan CC, Dana R, Figueiredo FC, Gomes JAP, Pellegrini G, Shimmura S, Kruse FE. Global consensus on definition, classification, diagnosis, and staging of limbal stem cell deficiency. Cornea. 2019;38:364-75.

12. Vazirani J, Nair D, Shanbhag S, Wurity S, Ranjan A, Sangwan V. Limbal stem cell deficiency-demography and underlying causes. Am J Ophthalmol. 2018;188:99-103.

13. Ghosh S, Salvador-Culla B, Kotagiri A, Pushpoth S, Tey A, Johnson ZK, Figueiredo FC. Acute chemical eye injury and limbal stem cell deficiency-a prospective study in the United Kingdom. Cornea. 2019;38:8-12.

14. Macdonald ECA, Cauchi PA, Azuara-Blanco A, Foot B. Surveillance of severe chemical corneal injuries in the UK. Br J Ophthalmol. 2009;93:1177-80.

15. Frey N, Jossi J, Bodmer M, Bircher A, Jick SS, Meier CR, Spoendlin J. The epidemiology of Stevens-Johnson syndrome and toxic epidermal necrolysis in the UK. J Investig Dermatol. 2017;137: 1240-7.

16. Shortt AJ, Tuft SJ, Daniels JT. Corneal stem cells in the eye clinic. Br Med Bull. 2011;100:209-25.

17. Chan CC, Holland EJ. Severe limbal stem cell deficiency from contact lens wear: patient clinical features. Am J Ophthalmol. 2013;155:544-549.e2. 
18. White ML, Chodosh J, Jang J, Dohlman C. Incidence of Stevens-Johnson syndrome and chemical burns to the eye. Cornea. 2015;34:1527-33.

19. Kang BS, Kim MK, Wee WR, Oh JY. Infectious keratitis in limbal stem cell deficiency: Stevens-Johnson syndrome versus chemical burn. Cornea. 2016;35:51-5.

20. Nair D, Mohamed A, Sangwan VS. Outcome of cataract surgery following simple limbal epithelial transplantation for lime injury-induced limbal stem cell deficiency. BMJ Case Rep. 2015;2015:1-3.

21. Rossen J, Amram A, Milani B, Park D, Harthan J, Joslin C, McMahon T, Djalilian A. Contact lens-induced limbal stem cell deficiency. Ocul Surf. 2016;14:419-34.

22. Shen C, Chan CC, Holland EJ. Limbal stem cell transplantation for soft contact lens wear-related limbal stem cell deficiency. Am J Ophthalmol. 2015;160:1142-1149.e1.

23. Vasquez-Perez A, Nanavaty MA. Modified allogenic simple limbal epithelial transplantation followed by keratoplasty as treatment for total limbal stem cell deficiency. Ocul Immunol Inflamm. 2018;26: 1189-91.

24. Khoo LW, Attzs M, Srinivasan S, Roberts F. Limbal stem cell deficiency secondary to diffuse nonnecrotizing anterior scleritis: a clinicopathological report. Cornea. 2018;37:1175-7.

25. Perez RL, Perez-Simon JA, Caballero-Velazquez T, et al. Limbus damage in ocular graft-versus-host disease. Biol Blood Marrow Transplant. 2011;17: 270-3.

26. Dua HS, Azuara-Blanco A. Allo-limbal transplantation in patients with limbal stem cell deficiency. Br J Ophthalmol. 1999;83:414-9.

27. Sravani NG, Mohamed A, Sangwan VS. Type 1 Boston keratoprosthesis for limbal stem cell deficiency in epidermolysis bullosa. Ocul Immunol Inflamm. 2019;27:282-4.

28. Fernandes M, Sangwan VS, Vemuganti GK. Limbal stem cell deficiency and xeroderma pigmentosum: a case report. Eye. 2004;18:741-3.

29. Vincent SJ, Lee GA. Paediatric idiopathic limbal stem cell deficiency. Cont Lens Anterior Eye. 2017;40:195-7.

30. Jawaheer L, Anijeet D, Ramaesh K. Diagnostic criteria for limbal stem cell deficiency-a systematic literature review. Surv Ophthalmol. 2017;62: 522-32.
31. Espandar L, Steele JF, Lathrop KL. Optical coherence tomography imaging of the palisades of Vogt to assist clinical evaluation and surgical planning in a case of limbal stem-cell deficiency. Eye Contact Lens. 2017;43:e19-e21.

32. Banayan N, Georgeon C, Grieve K, Borderie VM. Spectral-domain optical coherence tomography in limbal stem cell deficiency. A case-control study. Am J Ophthalmol. 2018;190:179-90.

33. Banayan N, Georgeon C, Grieve K, Ghoubay D, Baudouin F, Borderie V. In vivo confocal microscopy and optical coherence tomography as innovative tools for the diagnosis of limbal stem cell deficiency. J Fr Ophtalmol. 2018;41:e395-e406.

34. Zakaria N, Ni Dhubhghaill S, Taal M, Berneman Z, Koppen C, Tassignon M-J. Optical coherence tomography in cultivated limbal epithelial stem cell transplantation surgery. Asia Pac J Ophthalmol (Philadelphia, Pa). 2015;4:339-45.

35. Mehtani A, Agarwal MC, Sharma S, Chaudhary S. Diagnosis of limbal stem cell deficiency based on corneal epithelial thickness measured on anterior segment optical coherence tomography. Indian J Ophthalmol. 2017;65:1120-6.

36. Jirsova K, Dudakova L, Kalasova S, Vesela V, Merjava S. The OV-TL 12/30 clone of anti-cytokeratin 7 antibody as a new marker of corneal conjunctivalization in patients with limbal stem cell deficiency. Investig Ophthalmol Vis Sci. 2011;52:5892-8.

37. Chen P, Zhou Q, Wang J, Zhao X, Duan H, Wang Y, Liu T, Xie L. Characterization of the corneal surface in limbal stem cell deficiency and after transplantation of cultured allogeneic limbal epithelial cells. Graefes Arch Clin Exp Ophthalmol. 2016;254: 1765-77.

38. Barbaro V, Ferrari S, Fasolo A, Pedrotti E, Marchini G, Sbabo A, Nettis N, Ponzin D, Di Iorio E. Evaluation of ocular surface disorders: a new diagnostic tool based on impression cytology and confocal laser scanning microscopy. $\mathrm{Br} \mathrm{J}$ Ophthalmol. 2010;94:926-32.

39. Garcia I, Etxebarria J, Boto-De-Los-Bueis A, et al. Comparative study of limbal stem cell deficiency diagnosis methods: detection of MUC5AC mRNA and goblet cells in corneal epithelium. Ophthalmology. 2012;119:923-9.

40. Garcia I, Etxebarria J, Merayo-Lloves J, Torras J, Boto-de-Los-Bueis A, Diaz-Valle D, Mendez-Fernandez R, Acera A, Suarez-Cortes T. Novel molecular diagnostic system of limbal stem cell deficiency based on MUC5AC transcript detection in corneal epithelium by PCR-reverse dot blot. Investig Ophthalmol Vis Sci. 2013;54:5643-52. 
41. Le $\mathrm{Q}, \mathrm{Xu} \mathrm{J}$, Deng SX. The diagnosis of limbal stem cell deficiency. Ocul Surf. 2018;16:58-69.

42. Garcia I, Etxebarria J, Boto-de-Los-Bueis A, et al. Comparative study of limbal stem cell deficiency diagnosis methods: detection of MUC5AC mRNA and goblet cells in corneal epithelium. Ophthalmology. 2012;119:923-9.

43. Caro-Magdaleno M, Alfaro-Juarez A, MonteroIruzubieta J, Fernandez-Palacin A, Munoz-Morales A, Castilla-Martino MA, Spinola-Munoz C, Rodriguez-de-la-Rua E. In vivo confocal microscopy indicates an inverse relationship between the subbasal corneal plexus and the conjunctivalisation in patients with limbal stem cell deficiency. $\mathrm{Br} \mathrm{J}$ Ophthalmol. 2019;103:327-31.

44. Deng SX, Sejpal KD, Tang Q, Aldave AJ, Lee OL, Yu F. Characterization of limbal stem cell deficiency by in vivo laser scanning confocal microscopy: a microstructural approach. Arch Ophthalmol (Chicago, Ill 1960). 2012;130:440-5.

45. Miri A, Alomar T, Nubile M, Al-Aqaba M, Lanzini M, Fares U, Said DG, Lowe J, Dua HS. In vivo confocal microscopic findings in patients with limbal stem cell deficiency. Br J Ophthalmol. 2012;96:523-9.

46. Chuephanich P, Supiyaphun C, Aravena C, Bozkurt TK, Yu F, Deng SX. Characterization of the corneal subbasal nerve plexus in limbal stem cell deficiency. Cornea. 2017;36:347-52.

47. Patel DV, McGhee CN. Quantitative analysis of in vivo confocal microscopy images: a review. Surv Ophthalmol. 2013;58:466-75.

48. Giannaccare G, Pellegrini M, Sebastiani S, Moscardelli F, Versura P, Campos EC. In vivo confocal microscopy morphometric analysis of corneal subbasal nerve plexus in dry eye disease using newly developed fully automated system. Graefes Arch Clin Exp Ophthalmol. 2019;257:583-9.

49. Schaldemose EL, Fontain FI, Karlsson P, Nyengaard JR. Improved sampling and analysis of images in corneal confocal microscopy. J Microsc. 2017;268: 3-12.

50. Scarr D, Lovblom LE, Ostrovski I, et al. Agreement between automated and manual quantification of corneal nerve fiber length: Implications for diabetic neuropathy research. J Diabetes Complications. 2017;31:1066-73.

51. Annunziata R, Kheirkhah A, Aggarwal S, Hamrah P, Trucco E. A fully automated tortuosity quantification system with application to corneal nerve fibres in confocal microscopy images. Med Image Anal. 2016;32:216-32.
52. Bizheva K, Tan B, MacLellan B, Hosseinaee Z, Mason E, Hileeto D, Sorbara L. In-vivo imaging of the palisades of Vogt and the limbal crypts with sub-micrometer axial resolution optical coherence tomography. Biomed Opt Express. 2017;8:4141.

53. Kiritoshi S, Oie Y, Nampei K, Sato S, Morota M, Nishida K. Anterior segment optical coherence tomography angiography in patients following cultivated oral mucosal epithelial transplantation. Am J Ophthalmol. 2019;208:242-50.

54. Oie Y, Nishida K. Evaluation of corneal neovascularization using optical coherence tomography angiography in patients with limbal stem cell deficiency. Cornea. 2017;36(Suppl 1):S72-S7575.

55. Kim BY, Riaz KM, Bakhtiari P, Chan CC, Welder JD, Holland EJ, Basti S, Djalilian AR. Medically reversible limbal stem cell disease: clinical features and management strategies. Ophthalmology. 2014;121: 2053-8.

56. Young AL, Cheng ACO, Ng HK, Cheng LL, Leung GYS, Lam DSC. The use of autologous serum tears in persistent corneal epithelial defects. Eye. 2004;18: 609-14.

57. Na KS, Kim MS. Allogeneic serum eye drops for the treatment of dry eye patients with chronic graftversus-host disease. J Ocul Pharmacol Ther. 2012;28:479-83.

58. Chiang CC, Chen WL, Lin JM, Tsai YY. Allogeneic serum eye drops for the treatment of persistent corneal epithelial defect. Eye. 2009;23:290-3.

59. Yin J, Jacobs DS. Long-term outcome of using Prosthetic Replacement of Ocular Surface Ecosystem (PROSE) as a drug delivery system for bevacizumab in the treatment of corneal neovascularization. Ocul Surf. 2019;17:134-41.

60. Kenyon KR, Tseng SC. Limbal autograft transplantation for ocular surface disorders. Ophthalmology. 1989;96:709-22 (discussion 722-3).

61. Daya SM, Chan CC, Holland EJ. Cornea society nomenclature for ocular surface rehabilitative procedures. Cornea. 2011;30:1115-9.

62. Movahedan A, Cheung AY, Eslani M, Mogilishetty G, Govil A, Holland EJ. Long-term outcomes of ocular surface stem cell allograft transplantation. Am J Ophthalmol. 2017;184:97-107.

63. Eslani M, Haq Z, Movahedan A, Moss A, BaradaranRafii A, Mogilishetty G, Holland EJ, Djalilian AR. Late acute rejection after allograft limbal stem cell transplantation: evidence for long-term donor survival. Cornea. 2017;36:26-31. 
64. Yin J, Jurkunas U. Limbal stem cell transplantation and complications. Semin Ophthalmol. 2018;33: 134-41.

65. Gupta N, Farooqui JH, Patel N, Mathur U. Early results of penetrating keratoplasty in patients with unilateral chemical injury after simple limbal epithelial transplantation. Cornea. 2018;37: 1249-54.

66. Shah R, Puranik C, Mohamed A, Sangwan VS. Cultivated limbal epithelial transplantation and penetrating keratoplasty postchemical injury: a 14-year follow-up. BMJ Case Rep. 2017. https://doi.org/10. 1136/bcr-2016-217372.

67. Cheung AY, Sarnicola E, Holland EJ. Long-term ocular surface stability in conjunctival limbal autograft donor eyes. Cornea. 2017;36:1031-5.

68. Holland EJ. Epithelial transplantation for the management of severe ocular surface disease. Trans Am Ophthalmol Soc. 1996;94:677-743.

69. Lang SJ, Bohringer D, Geerling G, Reinhard T. Longterm results of allogenic penetrating limbo-keratoplasty: 20 years of experience. Eye (Lond). 2017;31: 372-8.

70. Moreira PB, Magalhaes RS, Pereira NC, de Oliveira LA, de Sousa LB. Limbal transplantation at a tertiary hospital in Brazil: a retrospective study. Arq Bras Oftalmol. 2015;78:207-11.

71. Jenkins C, Tuft S, Liu C, Buckley R. Limbal transplantation in the management of chronic contactlens- associated epitheliopathy. Eye. 1993;7:629-33.

72. Cheung AY, Sarnicola E, Govil A, Holland EJ. Combined conjunctival limbal autografts and living-related conjunctival limbal allografts for severe unilateral ocular surface failure. Cornea. 2017;36: 1570-5.

73. Shanbhag SS, Saeed HN, Paschalis EI, Chodosh J. Boston keratoprosthesis type 1 for limbal stem cell deficiency after severe chemical corneal injury: a systematic review. Ocul Surf. 2018;16:272-81.

74. Biber JM, Skeens HM, Neff KD, Holland EJ. The cincinnati procedure: technique and outcomes of combined living-related conjunctival limbal allografts and keratolimbal allografts in severe ocular surface failure. Cornea. 2011;30:765-71.

75. Chan CC, Biber JM, Holland EJ. The modified Cincinnati procedure: combined conjunctival limbal autografts and keratolimbal allografts for severe unilateral ocular surface failure. Cornea. 2012;31: 1264-72.
76. Pellegrini G, Dellambra E, Golisano O, Martinelli E, Fantozzi I, Bondanza S, Ponzin D, McKeon F, De Luca M. p63 identifies keratinocyte stem cells. Proc Natl Acad Sci USA. 2001;98:3156-61.

77. Pellegrini G, Rama P, Matuska S, et al. Biological parameters determining the clinical outcome of autologous cultures of limbal stem cells. Regen Med. 2013;8:553-67.

78. Rama P, Matuska S, Paganoni G, Spinelli A, De Luca M, Pellegrini G. Limbal stem-cell therapy and longterm corneal regeneration. N Engl J Med. 2010;363: 147-55.

79. Kolli S, Ahmad S, Mudhar HS, Meeny A, Lako M, Figueiredo FC. Successful application of ex vivo expanded human autologous oral mucosal epithelium for the treatment of total bilateral limbal stem cell deficiency. Stem Cells. 2014;32:2135-46.

80. Pellegrini G, Traverso CE, Franzi AT, Zingirian M, Cancedda R, De Luca M. Long-term restoration of damaged corneal surfaces with autologous cultivated corneal epithelium. Lancet. 1997;349:990-3.

81. Kolli S, Ahmad S, Lako M, Figueiredo F. Successful clinical implementation of corneal epithelial stem cell therapy for treatment of unilateral limbal stem cell deficiency. Stem Cells. 2010;28(3):597-610. https://doi.org/10.1002/stem.276.

82. Shortt AJ, Secker GA, Rajan MS, Meligonis G, Dart JK, Tuft SJ, Daniels JT. Ex vivo expansion and transplantation of limbal epithelial stem cells. Ophthalmology. 2008;115:1989-97.

83. Pellegrini G, Lambiase A, Macaluso C, Pocobelli A, Deng S, Cavallini GM, Esteki R, Rama P. From discovery to approval of an advanced therapy medicinal product-containing stem cells, in the EU. Regen Med. 2016;11:407-20.

84. Baylis O, Figueiredo FC, Henein C, Lako M, Ahmad S. 13 Years of cultured limbal epithelial cell therapy: a review of the outcomes. J Cell Biochem. 2011;112: 993-1002.

85. Pellegrini G, Ardigò D, Milazzo G, Iotti G, Guatelli P, Pelosi D, De Luca M. Navigating market authorization: the path holoclar took to become the first stem cell product approved in the European Union. Stem Cells Transl Med. 2018;7:146-54.

86. Tananuvat N, Bumroongkit K, Tocharusa C, Mevatee U, Kongkaew A, Ausayakhun S. Limbal stem cell and oral mucosal epithelial transplantation from ex vivo cultivation in LSCD-induced rabbits: histology and immunologic study of the transplant epithelial sheet. Int Ophthalmol. 2017;37:1289-98. 
87. Bobba S, Chow S, Watson S, Di Girolamo N. Clinical outcomes of xeno-free expansion and transplantation of autologous ocular surface epithelial stem cells via contact lens delivery: a prospective case series. Stem Cell Res Ther. 2015;6:23.

88. Behaegel J, Zakaria N, Tassignon M-J, Leysen I, Bock F, Koppen C, Ni Dhubhghaill S. Short- and longterm results of xenogeneic-free cultivated autologous and allogeneic limbal epithelial stem cell transplantations. Cornea. 2019;38:1543-9.

89. Mishan MA, Yaseri M, Baradaran-Rafii A, Kanavi MR. Systematic review and meta-analysis investigating autograft versus allograft cultivated limbal epithelial transplantation in limbal stem cell deficiency. Int Ophthalmol. 2019;39:2685-96.

90. Borderie VM, Ghoubay D, Georgeon C, Borderie M, de Sousa C, Legendre A, Rouard H. Long-term results of cultured limbal stem cell versus limbal tissue transplantation in stage III limbal deficiency. Stem Cells Transl Med. 2019;8:1230-41.

91. Genicio N, Gallo Paramo J, Shortt AJ. Quantum dot labeling and tracking of cultured limbal epithelial cell transplants in vitro. Investig Ophthalmol Vis Sci. 2015;56:3051-9.

92. Pedrotti E, Passilongo M, Fasolo A, et al. In vivo confocal microscopy 1 year after autologous cultured limbal stem cell grafts. Ophthalmology. 2015;122:1660-8.

93. Mikhailova A, Ilmarinen T, Ratnayake A, Petrovski G, Uusitalo H, Skottman H, Rafat M. Human pluripotent stem cell-derived limbal epithelial stem cells on bioengineered matrices for corneal reconstruction. Exp Eye Res. 2016;146:26-34.

94. Levis HJ, Daniels JT. Recreating the human limbal epithelial stem cell niche with bioengineered limbal crypts. Curr Eye Res. 2016;41:1153-60.

95. Koulikovska M, Rafat M, Petrovski G, Vereb Z, Akhtar S, Fagerholm P, Lagali N. Enhanced regeneration of corneal tissue via a bioengineered collagen construct implanted by a nondisruptive surgical technique. Tissue Eng Part A. 2015;21: 1116-30.

96. Osei-Bempong C, Ghareeb AE, Lako M, Figueiredo FC, Armitage WJ. Defining the optimal cryoprotectant and concentration for cryopreservation of limbal stem cells. Cryobiology. 2018;84:98-102.

97. Yeh H-J, Yao C-L, Chen H-I, Cheng H-C, Hwang S-M. Cryopreservation of human limbal stem cells ex vivo expanded on amniotic membrane. Cornea. 2008;27:327-33.
98. Sangwan VS, Basu S, MacNeil S, Balasubramanian D. Simple limbal epithelial transplantation (SLET): a novel surgical technique for the treatment of unilateral limbal stem cell deficiency. Br J Ophthalmol. 2012;96:931-4.

99. Mittal V, Jain R, Mittal R. Ocular surface epithelialization pattern after simple limbal epithelial transplantation: an in vivo observational study. Cornea. 2015;34:1227-322.

100. Vazirani J, Ali MH, Sharma N, et al. Autologous simple limbal epithelial transplantation for unilateral limbal stem cell deficiency: multicentre results. Br J Ophthalmol. 2016;100:1416-20.

101. Gupta N, Joshi J, Farooqui JH, Mathur U. Results of simple limbal epithelial transplantation in unilateral ocular surface burn. Indian J Ophthalmol. 2018;66:45-52.

102. Sotozono C, Inatomi $T$, Nakamura $T$, et al. Visual improvement after cultivated oral mucosal epithelial transplantation. Ophthalmology. 2013;120: 193-200.

103. Gain P, Jullienne R, He Z, Aldossary M, Acquart S, Cognasse F, Thuret G. Global survey of corneal transplantation and eye banking. JAMA Ophthalmol. 2016;134:167-73.

104. Nakamura T, Kinoshita S. Ocular surface reconstruction using cultivated mucosal epithelial stem cells. Cornea. 2003;22:S75-80.

105. Nakamura T, Inatomi T, Sotozono C, Amemiya T, Kanamura N, Kinoshita S. Transplantation of cultivated autologous oral mucosal epithelial cells in patients with severe ocular surface disorders. Br J Ophthalmol. 2004;88:1280-4.

106. Nishida K, Yamato M, Hayashida Y, et al. Corneal reconstruction with tissue-engineered cell sheets composed of autologous oral mucosal epithelium. N Engl J Med. 2004;351:1187-96.

107. Bardag-Gorce F, Oliva J, Wood A, Hoft R, Pan D, Thropay J, Makalinao A, French SW, Niihara Y. Carrier-free cultured autologous oral mucosa epithelial cell sheet (CAOMECS) for corneal epithelium reconstruction: a histological study. Ocul Surf. 2015;13:150-63.

108. Chen HCJ, Chen HL, Lai JY, Chen CC, Tsai YJ, Kuo MT, Chu PH, Sun CC, Chen JK, Ma DHK. Persistence of transplanted oral mucosal epithelial cells in human cornea. Investig Ophthalmol Vis Sci. 2009;50:4660-8.

109. Gopakumar V, Agarwal S, Srinivasan B, Krishnakumar S, Krishnan UM, Iyer G. Clinical outcome of autologous cultivated oral mucosal epithelial 
transplantation in ocular surface reconstruction. Cornea. 2019;38:1273-9.

110. Prabhasawat P, Ekpo P, Uiprasertkul M, Chotikavanich S, Tesavibul N, Pornpanich K, Luemsamran P. Long-term result of autologous cultivated oral mucosal epithelial transplantation for severe ocular surface disease. Cell Tissue Bank. 2016;17:491-503.

111. Choe HR, Yoon $\mathrm{CH}$, Kim MK. Ocular surface reconstruction using circumferentially-trephined autologous oral mucosal graft transplantation in limbal stem cell deficiency. Korean J Ophthalmol. 2019;33:16-25.

112. Burillon C, Huot L, Justin V, Nataf S, Chapuis F, Decullier E, Damour O. Cultured autologous oral mucosal epithelial cell sheet (CAOMECS) transplantation for the treatment of corneal limbal epithelial stem cell deficiency. Investig Ophthalmol Vis Sci. 2012;53:1325-31.

113. Nakamura $T$, Takeda $K$, Inatomi $T$, Sotozono $C$, Kinoshita S. Long-term results of autologous cultivated oral mucosal epithelial transplantation in the scar phase of severe ocular surface disorders. Br J Ophthalmol. 2011;95:942-6.

114. Man RC, Yong TK, Hwei NM, Halim WHWA, Zahidin AZM, Ramli R, Bin SA, Idrus RBH. Corneal regeneration by induced human buccal mucosa cultivated on an amniotic membrane following alkaline injury. Mol Vis. 2017;23:810-22.

115. Chen HCJ, Yeh LK, Tsai YJ, et al. Expression of angiogenesis-related factors in human corneas after cultivated oral mucosal epithelial transplantation. Investig Ophthalmol Vis Sci. 2012;53:5615-23.

116. Duan C-Y, Xie H-T, Zhao X-Y, Zhang M-C. Limbal niche cells: a novel feeder cell for autologous cultivated oral mucosal epithelial transplantation. Regen Med. 2019;14:49-62.

117. Pearton DJ, Yang Y, Dhouailly D. Transdifferentiation of corneal epithelium into epidermis occurs by means of a multistep process triggered by dermal developmental signals. Proc Natl Acad Sci USA. 2005;102:3714-9.

118. Pearton DJ, Ferraris C, Dhouailly D. Transdifferentiation of corneal epithelium: evidence for a linkage between the segregation of epidermal stem cells and the induction of hair follicles during embryogenesis. Int J Dev Biol. 2004;48:197-201.

119. Xu X, Mannik J, Kudryavtseva E, et al. Co-factors of LIM domains (Clims/Ldb/Nli) regulate corneal homeostasis and maintenance of hair follicle stem cells. Dev Biol. 2007;312:484-500.
120. Blazejewska EA, Schlotzer-Schrehardt U, Zenkel M, Bachmann B, Chankiewitz E, Jacobi C, Kruse FE. Corneal limbal microenvironment can induce transdifferentiation of hair follicle stem cells into corneal epithelial-like cells. Stem Cells. 2009;27: 642-52.

121. Meyer-Blazejewska EA, Call MK, Yamanaka O, Liu H, Schlotzer-Schrehardt U, Kruse FE, Kao WW. From hair to cornea: toward the therapeutic use of hair follicle-derived stem cells in the treatment of limbal stem cell deficiency. Stem Cells. 2011;29:57-66.

122. Gomes JAP, Geraldes Monteiro B, Melo GB, Smith RL, Pereira C, da Silva M, Lizier NF, Kerkis A, Cerruti $\mathrm{H}$, Kerkis I. Corneal reconstruction with tissueengineered cell sheets composed of human immature dental pulp stem cells. Investig Ophthalmol Vis Sci. 2010;51:1408-14.

123. Syed-Picard FN, Du Y, Lathrop KL, Mann MM, Funderburgh ML, Funderburgh JL. Dental pulp stem cells: a new cellular resource for corneal stromal regeneration. Stem Cells Transl Med. 2015;4: $276-85$.

124. Monteiro BG, Serafim RC, Melo GB, et al. Human immature dental pulp stem cells share key characteristic features with limbal stem cells. Cell Prolif. 2009;42:587-94.

125. Monteiro BG, Loureiro RR, Cristovam PC, Covre JL, Gomes JAP, Kerkis I. Amniotic membrane as a biological scaffold for dental pulp stem cell transplantation in ocular surface reconstruction. Arq Bras Oftalmol. 2019;82:32-7.

126. Kushnerev E, Shawcross SG, Sothirachagan S, Carley F, Brahma A, Yates JM, Hillarby MC. Regeneration of corneal epithelium with dental pulp stem cells using a contact lens delivery system. Investig Ophthalmol Vis Sci. 2016;57:5192-9.

127. Homma R, Yoshikawa H, Takeno M, Kurokawa MS, Masuda C, Takada E, Tsubota K, Ueno S, Suzuki N. Induction of epithelial progenitors in vitro from mouse embryonic stem cells and application for reconstruction of damaged cornea in mice. Investig Ophthalmol Vis Sci. 2004;45:4320-6.

128. Ueno H, Kurokawa MS, Kayama M, Homma R, Kumagai Y, Masuda C, Takada E, Tsubota K, Ueno S, Suzuki N. Experimental transplantation of corneal epithelium-like cells induced by Pax6 gene transfection of mouse embryonic stem cells. Cornea. 2007;26:1220-7.

129. Kumagai Y, Kurokawa MS, Ueno H, Kayama M, Tsubota K, Nakatsuji N, Kondo Y, Ueno S, Suzuki N. Induction of corneal epithelium-like cells from cynomolgus monkey embryonic stem cells and 
their experimental transplantation to damaged cornea. Cornea. 2010;29:432-8.

130. Zhang C, Du L, Sun P, Shen L, Zhu J, Pang K, Wu X. Construction of tissue-engineered full-thickness cornea substitute using limbal epithelial cell-like and corneal endothelial cell-like cells derived from human embryonic stem cells. Biomaterials. 2017;124:180-94.

131. Takahashi K, Tanabe K, Ohnuki M, Narita M, Ichisaka T, Tomoda K, Yamanaka S. Induction of pluripotent stem cells from adult human fibroblasts by defined factors. Cell. 2007;131:861-72.

132. Mikhailova A, Ilmarinen T, Uusitalo H, Skottman H. Small-molecule induction promotes corneal epithelial cell differentiation from human induced pluripotent stem cells. Stem Cell Rep. 2014;2: 219-31.

133. Hongisto H, Vattulainen M, Ilmarinen T, Mikhailova A, Skottman H. Efficient and scalable directed differentiation of clinically compatible corneal limbal epithelial stem cells from human pluripotent stem cells. J Vis Exp. 2018. https://doi.org/10.3791/ 58279 .

134. Cieslar-Pobuda A, Rafat M, Knoflach V, Skonieczna M, Hudecki A, Malecki A, Urasinska E, Ghavami S, Los MJ. Human induced pluripotent stem cell differentiation and direct transdifferentiation into corneal epithelial-like cells. Oncotarget. 2016;7: 42314-29.

135. Susaimanickam PJ, Maddileti S, Pulimamidi VK, Boyinpally SR, Naik RR, Naik MN, Reddy GB, Sangwan VS, Mariappan I. Generating minicorneal organoids from human induced pluripotent stem cells. Development. 2017;144:2338-511.

136. Hayashi R, Ishikawa Y, Katayama T, Quantock AJ, Nishida K. CD200 facilitates the isolation of corneal epithelial cells derived from human pluripotent stem cells. Sci Rep. 2018;8:16550.

137. Hayashi R, Ishikawa Y, Sasamoto Y, et al. Co-ordinated ocular development from human iPS cells and recovery of corneal function. Nature. 2016;531: $376-80$.

138. Hayashi R, Ishikawa Y, Katori R, Sasamoto Y, Taniwaki Y, Takayanagi $\mathrm{H}$, Tsujikawa M, Sekiguchi K, Quantock AJ, Nishida K. Coordinated generation of multiple ocular-like cell lineages and fabrication of functional corneal epithelial cell sheets from human iPS cells. Nat Protoc. 2017;12:683-96.

139. Yamada K, Young RD, Lewis PN, Shinomiya K, Meek KM, Kinoshita S, Caterson B, Quantock AJ. Mesenchymal-epithelial cell interactions and proteoglycan matrix composition in the presumptive stem cell niche of the rabbit corneal limbus. Mol Vis. 2015;21:1328-39.

140. Al-Jaibaji O, Swioklo S, Connon CJ. Mesenchymal stromal cells for ocular surface repair. Expert Opin Biol Ther. 2019;19:643-53.

141. Hertsenberg AJ, Shojaati G, Funderburgh ML, Mann MM, Du Y, Funderburgh JL. Corneal stromal stem cells reduce corneal scarring by mediating neutrophil infiltration after wounding. PLOS ONE. 2017;12:1-16.

142. Calonge M, Pérez I, Galindo S, Nieto-Miguel T, López-Paniagua M, Fernández I, Alberca M, GarcíaSancho J, Sánchez A, Herreras JM. A proof-of-concept clinical trial using mesenchymal stem cells for the treatment of corneal epithelial stem cell deficiency. Transl Res. 2019;206:18-40.

143. Yazdanpanah G, Haq Z, Kang K, Jabbehdari S, Rosenblatt ML, Djalilian AR. Strategies for reconstructing the limbal stem cell niche. Ocul Surf. 2019;17:230-40.

144. Richardson A, Park M, Watson SL, Wakefield D, Di Girolamo N. Visualizing the fate of transplanted K14-confetti corneal epithelia in a mouse model of limbal stem cell deficiency. Investig Ophthalmol Vis Sci. 2018;59:1630-40.

145. Segel M, Neumann B, Hill MFE, et al. Niche stiffness underlies the ageing of central nervous system progenitor cells. Nature. 2019;573:130-4.

146. Trappmann B, Gautrot JE, Connelly JT, et al. Extracellular-matrix tethering regulates stem-cell fate. Nat Mater. 2012;11:642-9.

147. Kolli S, Bojic S, Ghareeb AE, Kurzawa-Akanbi M, Figueiredo FC, Lako M. The role of nerve growth factor in maintaining proliferative capacity, colonyforming efficiency, and the limbal stem cell phenotype. Stem Cells. 2019;37:139-49.

148. Nasser W, Amitai-Lange A, Soteriou D, Hanna R, Tiosano B, Fuchs Y, Shalom-Feuerstein R. Cornealcommitted cells restore the stem cell pool and tissue boundary following injury. Cell Rep. 2018;22: 323-31.

149. Figueiredo GS, Bojic S, Rooney P, et al. Gamma-irradiated human amniotic membrane decellularised with sodium dodecyl sulfate is a more efficient substrate for the ex vivo expansion of limbal stem cells. Acta Biomater. 2017;61:124-33.

150. Irani YD, Klebe S, McInnes SJP, Jasieniak M, Voelcker NH, Williams KA. Oral mucosal epithelial cells grown on porous silicon membrane for transfer to the rat eye. Sci Rep. 2017;7:10042. 